Research Article

\title{
Thermodynamic and Extrathermodynamic Studies of Enantioseparation of Imidazolinone Herbicides on Chiralcel OJ Column
}

\author{
Wenjian Lao \\ Department of Environmental Sciences, University of California, Riverside, CA 92521, USA \\ Correspondence should be addressed to Wenjian Lao; laowjbj@hotmail.com
}

Received 26 March 2013; Accepted 22 April 2013

Academic Editors: S. De Marino, Z. Liu, M. P. Marszall, and M. L. Trehy

Copyright (C) 2013 Wenjian Lao. This is an open access article distributed under the Creative Commons Attribution License, which permits unrestricted use, distribution, and reproduction in any medium, provided the original work is properly cited.

\begin{abstract}
A homologous series of chiral imidazolinone herbicide was previously resolved on Chiralcel OJ column in high performance liquid chromatography. However, the mechanism of the chiral separation remains unclear. In this study, chromatographic behaviors of five chiral imidazolinone herbicides were characterized by thermodynamic and extrathermodynamic methods in order to enhance the understanding of the chiral separation. Thermodynamic parameters of this study were derived from equilibrium constant $(K)$ that was estimated from the moment analysis of the chromatographic peak. Van't Hoff plots of $K(\ln K$ versus $1 / T)$ were linear at a range of $15-50^{\circ} \mathrm{C}$, only nonlinear at a range of $5-15^{\circ} \mathrm{C}$ with n-hexane $(0.1 \%$, trifluoroacetic acid)-2-propanol $60 / 40$ (v/v) mobile phase. The enantiomer retention on the chiral column was entropy-driven at a lower temperature $\left(5^{\circ} \mathrm{C}\right)$ and enthalpy-driven at a higher temperature $\left(10\right.$ to $\left.50^{\circ} \mathrm{C}\right)$. Enantioseparations of four of the five imidazolinone herbicides were enthalpy-driven, only entropy-driven for imazaquin. Enantioseparation mechanisms were different in between $5-10^{\circ} \mathrm{C}$ and $15-50^{\circ} \mathrm{C}$ probably due to the conformational change of the OJ phase. Enthalpy-entropy compensation showed similar mechanisms in retention and chiral separation for the five $S(-)$ or $R(+)$ enantiomers. Several extrathermodynamic relationships were able to be extracted to address additivity of group contribution.
\end{abstract}

\section{Introduction}

Chiral separation in high-performance liquid chromatography (HPLC) is keeping to be of great interest in diverse areas such as the agrochemicals and pharmaceutical industry [1]. To achieve better resolution and improve chiral stationary phase, enantioseparation mechanisms have been studied extensively using various methods [2-4]. A thermodynamic study is found to be especially valuable for providing information on the separation mechanism [5-7]. A link between chromatographic behavior and thermodynamic parameters such as enthalpy $\left(\Delta H^{\circ}\right)$, entropy $\left(\Delta S^{\circ}\right)$, and Gibbs free energy $\left(\Delta G^{\circ}\right)$ is distribution constant $(K)$ that describes the transfer of an analyte from mobile phase to stationary phase [8]. Moment analysis of elution peak based on a kinetic model provides an approach to estimate the $K$ value [9]. The present study is concerned with using the $K$ value to characterize retention and chiral separation, a case where there has been so far few works [10].
Extrathermodynamic relationships are empirical correlations of thermodynamic parameters with molecular structures, chromatographic conditions, and enthalpy-entropy compensation (EEC) and have been among the most important tools in investigation of separation mechanism [11, 12]. Many extrathermodynamic relationships have been developed to facilitate the understanding of chromatographic retention and separation mechanism [13]. Typically, it has been demonstrated that the extrathermodynamic relationship derived from homologous series of analytes with additive group such as methylene or phenyl is able to provide useful information on chromatographic behavior [14, 15]. Since lots of extrathermodynamic relationships such as EEC were established based on thermodynamic parameters, many extrathermodynamic studies were correspondingly implemented with the thermodynamic work $[6,16,17]$.

Imidazolinone herbicides including six structurally similar chiral compounds are extensively used in the field. 
<smiles>CC(C)[C@]1(C)N=C(c2ncccc2C(=O)O)NC1=O</smiles>

Imazapyr

1<smiles>Cc1cnc(C2=NC(C)(C(C)C)C(=O)N2)c(C(=O)O)c1</smiles>

Imazapic 2<smiles>CCc1cnc(C2=NC(C)(C(C)C)C(=O)N2)c(C(=O)O)c1</smiles>

Imazethapyr

3<smiles>COCc1cnc(C2=NC(C)(C(C)C)C(=O)N2)c(C(=O)O)c1</smiles>

Imazamox

4<smiles>CC(C)C1(C)N=C(c2nc3ccccc3cc2C(=O)O)NC1=O</smiles>

Imazaquin

5

FIGURE 1: Structures of the imidazolinone herbicide.

In a previous study, enantioseparation for five of these compounds was achieved on a Chiralcel OJ column (Figure 1) [18]. The five imidazolinone compounds are a homologous series that has different additive groups on imazapyr (1). Although there have been many studies on enantioseparation of OJ column, few studies have been addressed with the effect of temperature and thermodynamic characteristics [19-21]. The main objective of this study was to examine thermodynamic and extrathermodynamic characteristics of chromatographic behaviors for imidazolinone herbicides on the $\mathrm{OJ}$ column.

\section{Experimental}

2.1. Chemicals. Imazapyr (1) (99\%), imazapic (2) (99\%), imazethapyr (3) (99\%), imazamox (4) (99\%), and imazaquin (5) (99\%) were purchased from Chem Service (West Chester, PA. USA). Trifluoroacetic acid (TFA) (99\%) and 1,3,5-tri-tertbutylbenzene (TTBB) $(\geq 97.0 \%)$ were obtained from Sigma Aldrich (Milwaukee, WI). Solvents n-hexane and 2-propanol (HPLC grade) were purchased from Fisher (Springfield, NJ, USA).

2.2. Apparatus. All measurements were made on an Agilent 1100 HPLC systems (Agilent, Wilmington, DE, USA). Column temperatures at the range of $15-50^{\circ} \mathrm{C}$ were controlled by the thermostatic column compartment of the instrument itself. Column temperature at 5 and $10^{\circ} \mathrm{C}$ was achieved by surrounding the column in a coolant-jacketed cylinder coupled to a thermostat (LAUDA $K-2 / R$, Brinkmann Instruments, Germany). The column was a Chiralcel OJ (cellulose 4methylbenzoate, $250 \times 4.6 \mathrm{~mm}$ ID with $10 \mu \mathrm{m}$ particle size, Chiral Technologies, West Chester, PA, USA).
2.3. Chromatography. The analyte concentration was $0.2 \mathrm{mg} /$ $\mathrm{mL}$ prepared in the mobile phase. The injection volume was $20 \mu \mathrm{L}$. The flow rate of mobile phase was $1.0 \mathrm{~mL} / \mathrm{min}$, and the detection wavelength was $254 \mathrm{~nm}$ with $4 \mathrm{~nm}$ bandwidth. The hold-up time $\left(t_{0}\right)$ of the chromatographic system was measured by TTBB for every temperature and mobile phase composition. The extra volume $\left(t_{\text {ext }}\right)$ of the instrument system was measured by injecting TTBB solution into the instrument from the pump with a zero-dead volume connector in place of the column. The average $t_{\text {ext }}$ value of the Agilent 1100 HPLC system was $0.071 \mathrm{~min}$ with $\mathrm{n}$-hexane (0.1\%, TFA)2-propanol 70/30 and 60/40 (v/v) as the mobile phases. The column temperature was changed stepwise at $15,25,35,45$, and $50^{\circ} \mathrm{C}$ for $85 / 15,80 / 20,75 / 25,70 / 30$ and $60 / 40(\mathrm{v} / \mathrm{v})$ mobile phases. The column temperatures of 5 and $10^{\circ} \mathrm{C}$ were only investigated for 70/30, and 60/40 (v/v) mobile phases. The column was equilibrated with the mobile phase for $1 \mathrm{~h}$ at each temperature before sample injection. The $S(-)$ enantiomer was first eluted followed by the $R(+)$ enantiomer for all the five imidazolinone herbicides on OJ column [22].

2.4. Data Analysis. In a chromatographic system, retention is related to the change of Gibbs free energy at equilibrium:

$$
\ln K=-\frac{\Delta G^{\circ}}{R T}=-\frac{\Delta H^{\circ}}{R T}+\frac{\Delta S^{\circ}}{R},
$$

where $\Delta G^{\circ}, \Delta H^{\circ}$, and $\Delta S^{\circ}$ are the differences in the molar Gibbs free energy, the molar enthalpy, and molar entropy, respectively; $R$ is the gas constant; $T$ is the absolute temperature in Kelvin; $K$ is the distribution constant of the solute between stationary phase and mobile phase. According to the moment analysis method, the first absolute moment $\left(\mu_{1}\right)$ of 
the elution peak equals its retention time $\left(t_{R}\right)$ when the peak profile is symmetrical [11]

$$
\mu_{1}=t_{R}=\frac{\int C(t) t d t}{\int C(t) d t}=\left(t_{0}-t_{\text {ext }}\right)\left[1+\frac{1-\varepsilon}{\varepsilon} K\right],
$$

where $c(t)$ is the profile of the elution peak and $\varepsilon$ is total porosity of the column $\left(\varepsilon=V_{m} / V_{g}=f t_{0} / 0.25 \pi d^{2} L\right.$, where $V_{m}$ is the total volume of the mobile phase in the column, $V_{g}$ is the geometrical volume of the column, $f$ is the mobile phase flow rate, $d$ is the diameter of the column tube, and $L$ is the length of the column). From (2), $K$ is given by

$$
K=\frac{C_{s}}{C_{m}}=\frac{k}{\Phi}=\frac{t_{R}-\left(t_{0}-t_{\mathrm{ext}}\right)}{\left(t_{0}-t_{\mathrm{ext}}\right)} \frac{\varepsilon}{1-\varepsilon},
$$

where $C_{s}$ and $C_{m}$ are the concentration of the solute in the stationary phase and mobile phase at equilibrium, respectively, $k$ is retention factor, and $\Phi$ is column phase ratio.

When enantioseparation is achieved with a separation factor $\alpha$, the difference in enthalpy and entropy of the two enantiomers is given by

$$
\ln \alpha=\ln \frac{k_{2}}{k_{1}}=\ln \frac{K_{2}}{K_{1}}=-\frac{\Delta\left(\Delta H^{\circ}\right)}{R T}+\frac{\Delta\left(\Delta S^{\circ}\right)}{R} .
$$

For nonlinear van't Hoff behavior, dependence of $\ln K$ and $1 / T$ can be estimated by a quadratic form

$$
\ln K=A+\frac{B}{T}+\frac{C}{T},
$$

where the coefficients $A, B$, and $C$ can be estimated by nonlinear regression methods. $\Delta H^{\circ}$ and $\Delta S^{\circ}$ can then be obtained by

$$
\begin{gathered}
\Delta H^{\circ}=-R\left(B+\frac{2 C}{T}\right), \\
\Delta S^{\circ}=R\left(A-\frac{C}{T^{2}}\right) .
\end{gathered}
$$

Equations (6) show that $\Delta H^{\circ}$ and $\Delta S^{\circ}$ are temperature dependent with nonlinear van't Hoff behavior [12].

The EEC phenomenon has been used to estimate the retention and enantioseparation mechanisms of chromatographic systems [7-9]. The EEC on the retention is expressed by

$$
\Delta H^{\circ}=\beta \Delta S^{\circ}+\Delta G_{\beta}^{\circ},
$$

where $\Delta G_{\beta}^{\circ}$ is the Gibbs free energy at a compensation temperature $\beta$. The EEC on the separation factor can be expressed as

$$
\Delta\left(\Delta H^{\circ}\right)=\beta \Delta\left(\Delta S^{\circ}\right)+\Delta\left(\Delta G^{\circ}\right)_{\beta} .
$$

At the compensation temperature of separation factor, separation factor $\alpha$ is given by

$$
\ln \alpha_{\beta}=-\frac{\Delta\left(\Delta G_{\beta}^{\circ}\right)}{R T_{\beta}} .
$$

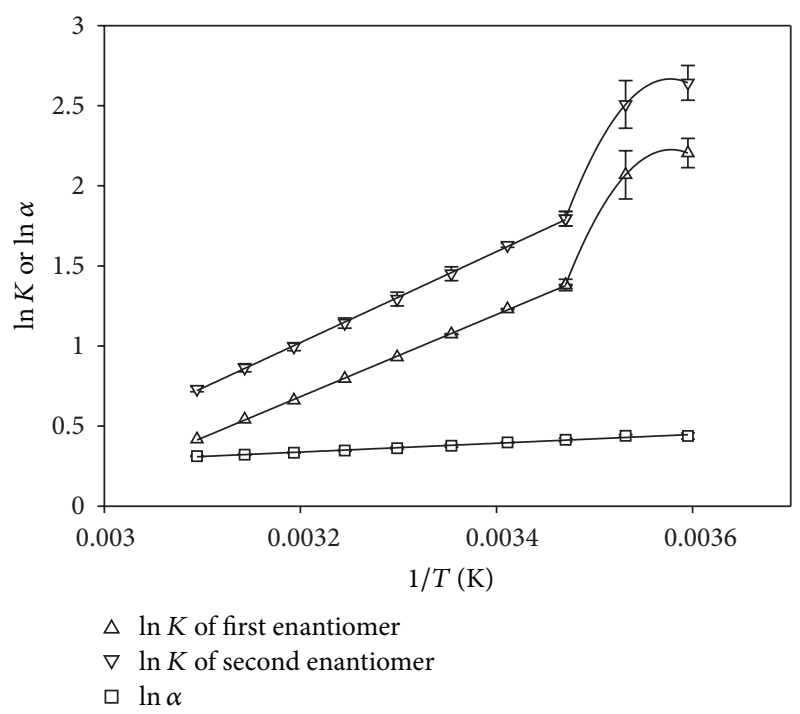

Figure 2: Van't Hoff plots of $K$ and $\alpha$ of imazamox at range of 5$50^{\circ} \mathrm{C}$ with $60 / 40$ mobile phase.

If the EEC is observed, it just means that the retention or enantioseparation may be similar. Reversely, an obvious different EEC can certify different retention or enantioseparation mechanisms [23]. Applying Martin's additive-freeenergy relationship [13], a functional group contribution to thermodynamic quantities can be written as

$$
\begin{gathered}
\Delta\left(\Delta H_{e}^{\circ}\right)_{i-j}=\left(\Delta H_{e}^{\circ}\right)_{i}-\left(\Delta H_{e}^{\circ}\right)_{j}, \\
\Delta\left(\Delta S_{e}^{\circ}\right)_{i-j}=\left(\Delta S_{e}^{\circ}\right)_{i}-\left(\Delta S_{e 1}^{\circ}\right)_{j}, \\
\Delta\left(\Delta G_{e}^{\circ}\right)_{i-j}=\left(\Delta G_{e}^{\circ}\right)_{i}-\left(\Delta G_{e}^{\circ}\right)_{j},
\end{gathered}
$$

where subscript $e$ represents $S(e=1)$ or $R(e=2)$ enantiomer and $i$ and $j$ represent the different imidazolinone herbicides.

\section{Results and Discussion}

3.1. Effect of Molecular Structure on Thermodynamic Parameters. Van't Hoff plots of $K$ and $\alpha$ were linear within $15-50^{\circ} \mathrm{C}$. Nonlinear van't Hoff plots of $K$ were obtained only at range of $5-15^{\circ} \mathrm{C}$ with $60 / 40(\mathrm{v} / \mathrm{v})$ mobile phase (Figure 2).

3.1.1. Thermodynamic Parameters at $15-50^{\circ} \mathrm{C}$. Generally, values of $\Delta H^{\circ}, \Delta S^{\circ}$, and $\Delta G^{\circ}$ were negative for all the enantiomers (Table 1), suggesting that their retentions were enthalpy-driven. The first-eluted $S(-)$ enantiomer of imazapyr (1) presented the highest $\Delta H^{\circ}$ value among the five compounds with 85/15 mobile phase. When the hydrogen atom at $\mathrm{C} 5$ position of imazapyr (1) pyridine ring (Figure 1) was substituted by a methyl and an ethyl group to form imazapic (2) and imazethapyr (3), the $\Delta H^{\circ}$ decreased by 1.4 and $0.9 \mathrm{~kJ} \mathrm{~mol}^{-1}$, respectively. The smallest $\Delta H^{\circ}$ belonged to imazamox (4), which was less by $3.2 \mathrm{~kJ} \mathrm{~mol}^{-1}$ than imazapyr (1). Imazaquin (5) had almost equal $\Delta H^{\circ}$ to imazapyr (1). On the other hand, the variation of $\Delta H^{\circ}$ for the $R(+)$ enantiomer 
TABLE 1: Thermodynamic parameters of the imidazolinone herbicides.

\begin{tabular}{|c|c|c|c|c|c|c|c|}
\hline Compound & Mobile phase & $\begin{array}{c}\Delta H_{S}^{\circ} \\
\mathrm{kJ} \mathrm{mol}^{-1}\end{array}$ & $\begin{array}{c}\Delta H_{R}^{\circ} \\
\mathrm{kJ} \mathrm{mol}^{-1}\end{array}$ & $\begin{array}{c}\Delta S_{S}^{\circ} \\
\mathrm{J} \mathrm{mol}^{-1} \mathrm{~K}^{-1}\end{array}$ & $\begin{array}{c}\Delta S_{R}^{\circ} \\
\mathrm{J} \mathrm{mol}^{-1} \mathrm{~K}^{-1}\end{array}$ & $\begin{array}{c}\Delta G_{S(303 \mathrm{~K})}^{\circ} \\
\mathrm{kJ} \mathrm{mol}^{-1}\end{array}$ & $\begin{array}{c}\Delta G_{R(303 \mathrm{~K})}^{\circ} \\
\mathrm{kJ} \mathrm{mol}^{-1}\end{array}$ \\
\hline \multirow{5}{*}{ Imazapyr } & $85 / 15$ & -22.56 & -27.02 & -51.07 & -60.86 & -7.08 & -8.58 \\
\hline & $80 / 20$ & -21.10 & -25.64 & -50.66 & -60.91 & -5.75 & -7.19 \\
\hline & $75 / 25$ & -20.48 & -24.89 & -52.19 & -62.22 & -4.66 & -6.04 \\
\hline & $70 / 30$ & -20.60 & -25.06 & -55.38 & -65.70 & -3.82 & -5.16 \\
\hline & $60 / 40$ & -18.19 & -21.97 & -51.89 & -60.32 & -2.47 & -3.69 \\
\hline \multirow{5}{*}{ Imazapic } & $85 / 15$ & -24.00 & -27.50 & -57.42 & -64.62 & -6.60 & -7.92 \\
\hline & $80 / 20$ & -22.56 & -26.02 & -56.84 & -64.08 & -5.33 & -6.61 \\
\hline & $75 / 25$ & -21.83 & -25.29 & -57.86 & -65.23 & -4.30 & -5.53 \\
\hline & $70 / 30$ & -21.87 & -25.52 & -60.60 & -68.71 & -3.50 & -4.70 \\
\hline & $60 / 40$ & -19.57 & -22.64 & -57.25 & -63.71 & -2.23 & -3.34 \\
\hline \multirow{5}{*}{ Imazethapyr } & $85 / 15$ & -23.42 & -25.19 & -58.68 & -61.22 & -5.64 & -6.64 \\
\hline & $80 / 20$ & -21.96 & -23.74 & -57.96 & -60.67 & -4.40 & -5.36 \\
\hline & $75 / 25$ & -21.22 & -23.08 & -58.83 & -61.94 & -3.39 & -4.31 \\
\hline & $70 / 30$ & -21.26 & -23.12 & -61.48 & -64.71 & -2.63 & -3.51 \\
\hline & $60 / 40$ & -19.06 & -20.66 & -58.22 & -60.85 & -1.42 & -2.22 \\
\hline \multirow{5}{*}{ Imazamox } & $85 / 15$ & -25.73 & -27.19 & -60.95 & -62.19 & -7.26 & -8.35 \\
\hline & $80 / 20$ & -24.49 & -26.00 & -61.19 & -62.78 & -5.95 & -6.98 \\
\hline & $75 / 25$ & -23.99 & -25.58 & -63.11 & -65.06 & -4.87 & -5.86 \\
\hline & $70 / 30$ & -24.17 & -25.85 & -66.43 & -68.81 & -4.04 & -5.00 \\
\hline & $60 / 40$ & -21.92 & -23.45 & -63.38 & -65.50 & -2.72 & -3.60 \\
\hline \multirow{5}{*}{ Imazaquin } & $85 / 15$ & -23.26 & -23.40 & -51.45 & -50.23 & -7.67 & -8.18 \\
\hline & $80 / 20$ & -21.84 & -21.97 & -51.15 & -49.95 & -6.34 & -6.84 \\
\hline & $75 / 25$ & -21.11 & -21.23 & -52.34 & -51.14 & -5.25 & -5.73 \\
\hline & $70 / 30$ & -21.08 & -21.19 & -55.01 & -53.84 & -4.41 & -4.87 \\
\hline & $60 / 40$ & -17.81 & -17.83 & -48.86 & -47.49 & -3.01 & -3.44 \\
\hline
\end{tabular}

Subscripts $S$ and $R$ denote the $S(-)$ and $R(+)$ enantiomers. Chromatographic conditions: Chiralcel OJ column; flow rate, $1 \mathrm{~mL} / \mathrm{min}$; detection wavelength, $254 \mathrm{~nm}$; mobile phase, $\mathrm{n}$-hexane (0.1\%TFA)-2-propanol (v/v); column temperature, $15-50^{\circ} \mathrm{C}$.

was different from the $S(-)$ enantiomer. Imazaquin (5) had the highest $\Delta H^{\circ}$ value. Values of $\Delta S^{\circ}$ for the $S(-)$ enantiomers decreased in an order of imazapyr $(1) \approx$ imazaquin $(5)>$ imazapic (2) > imazethapyr (3) > imazamox (4) with 85/15 $(\mathrm{v} / \mathrm{v})$ mobile phase. Values of $\Delta S^{\circ}$ for the $R(+)$ enantiomer of imazapyr (1), imazapic (2), imazethapyr (3), and imazamox (4) were all less than their $S(-)$ enantiomers, but only imazaquin (5) was reversed.

The high $\Delta S^{\circ}$ of imazapyr (1) suggested that its enantiomers had large movement freedom in chiral cavity of the OJ phase, likely due to its smaller molecular size [24]. The lowest value of $\Delta S^{\circ}$ for imazapic (2) $R(+)$ enantiomer indicated that it is possible to fit in the chiral cavity better than the other enantiomers. The highest $\Delta S^{\circ}$ for imazaquin (5) could be resulted from its bulk molecular size which diminishes the fitting degree to the chiral cavity. Consequently, the effect of steric factor appeared to play an important role in enantiorecognition on the OJ column [25].

Imazaquin (5) had positive $\Delta\left(\Delta S^{\circ}\right)$ and a very small $-\Delta\left(\Delta H^{\circ}\right)$ indicating that its chiral separation was entropydriven (Table 2). The other four herbicides had negative values for both $\Delta\left(\Delta H^{\circ}\right)$ and $\Delta\left(\Delta S^{\circ}\right)$ suggesting enthalpydriven chiral separations. The decrease of $-\Delta\left(\Delta H^{\circ}\right)$ and $-\Delta\left(\Delta S^{\circ}\right)$ followed an order imazapyr (1) > imazapic (2) > imazethapyr (3) > imazamox (4) > imazaquin (5), which was consistent with the increase of substituent dimension on the pyridine ring. The decrease in $-\Delta\left(\Delta G^{\circ}\right)$ followed a similar trend to that for $-\Delta\left(\Delta H^{\circ}\right)$ or $-\Delta\left(\Delta S^{\circ}\right)$, with the exception for imazethapyr (3) and imazamox (4). With the entropy compensation, $-\Delta\left(\Delta G^{\circ}\right)$ of imazamox (4) was larger than that of imazethapyr (3). The value of $-\Delta\left(\Delta H^{\circ}\right)$ for imazaquin (5) was very small, which reflected a poor steric fitness to the CSP. However, the positive $\Delta\left(\Delta S^{\circ}\right)$ made a counterbalance to achieve the enantioseparation.

In order to evaluate the relative contribution of enthalpy and entropy to the enantioseparation, enthalpy-entropy ratio $Q\left[Q=\Delta\left(\Delta H^{\circ}\right) /\left(303 \times \Delta\left(\Delta S^{\circ}\right)\right]\right.$ at $303 \mathrm{~K}$ was calculated (Table 2) [26]. The calculated $Q$ followed an order of imazamox (4) > imazethapyr (3) > imazapic (2) > imazapyr (1) > imazaquin (5). The $Q$ values of imazapyr (1), imazapic (2), imazethapyr (3), and imazamox (4) were positive and greater than 1 , indicating the larger molecule for imazamox (4), imazethapyr (3), imazapic (2), and imazapyr (1), the greater contribution to enthalpy. Imazaquin (5) had a positive $Q$ value, revealing that the large and rigid quinoline moiety may exert a different effect on solute-CSP complexation to cause a greater entropic contribution [27]. 
TABLE 2: Thermodynamic parameters $\Delta \Delta H^{\circ}, \Delta \Delta S^{\circ}$, and $\Delta \Delta G_{(303 \mathrm{~K})}^{\circ}$ of chiral separation.

\begin{tabular}{|c|c|c|c|c|c|}
\hline Compound & Mobile phase & $\begin{array}{c}\Delta \Delta H^{\circ} \\
\mathrm{kJ} \mathrm{mol}{ }^{-1}\end{array}$ & $\begin{array}{c}\Delta \Delta S^{\circ} \\
\mathrm{J} \mathrm{mol}^{-1} \mathrm{~K}^{-1}\end{array}$ & $\begin{array}{c}\Delta \Delta G_{(303 \mathrm{~K})}^{\circ} \\
\mathrm{kJ} \mathrm{mol}^{-1}\end{array}$ & $Q_{(303 \mathrm{~K})}^{*}$ \\
\hline \multirow{5}{*}{ Imazapyr } & $85 / 15$ & -4.47 & -9.80 & -1.50 & 1.50 \\
\hline & $80 / 20$ & -4.54 & -10.25 & -1.44 & 1.46 \\
\hline & $75 / 25$ & -4.42 & -10.03 & -1.38 & 1.45 \\
\hline & $70 / 30$ & -4.46 & -10.32 & -1.33 & 1.43 \\
\hline & $60 / 40$ & -3.78 & -8.43 & -1.23 & 1.48 \\
\hline \multirow{5}{*}{ Imazapic } & $85 / 15$ & -3.51 & -7.20 & -1.32 & 1.61 \\
\hline & $80 / 20$ & -3.47 & -7.24 & -1.27 & 1.58 \\
\hline & $75 / 25$ & -3.46 & -7.36 & -1.23 & 1.55 \\
\hline & $70 / 30$ & -3.66 & -8.11 & -1.20 & 1.49 \\
\hline & $60 / 40$ & -3.07 & -6.46 & -1.11 & 1.57 \\
\hline \multirow{5}{*}{ Imazethapyr } & $85 / 15$ & -1.77 & -2.54 & -1.00 & 2.30 \\
\hline & $80 / 20$ & -1.78 & -2.71 & -0.95 & 2.16 \\
\hline & $75 / 25$ & -1.85 & -3.11 & -0.91 & 1.97 \\
\hline & $70 / 30$ & -1.85 & -3.23 & -0.88 & 1.90 \\
\hline & $60 / 40$ & -1.60 & -2.63 & -0.80 & 2.01 \\
\hline \multirow{5}{*}{ Imazamox } & $85 / 15$ & -1.45 & -1.23 & -1.08 & 3.89 \\
\hline & $80 / 20$ & -1.51 & -1.58 & -1.03 & 3.15 \\
\hline & $75 / 25$ & -1.58 & -1.95 & -0.99 & 2.68 \\
\hline & $70 / 30$ & -1.68 & -2.38 & -0.96 & 2.33 \\
\hline & $60 / 40$ & -1.53 & -2.12 & -0.89 & 2.38 \\
\hline \multirow{5}{*}{ Imazaquin } & $85 / 15$ & -0.14 & 1.22 & -0.51 & \\
\hline & $80 / 20$ & -0.13 & 1.19 & -0.49 & \\
\hline & $75 / 25$ & -0.11 & 1.20 & -0.48 & \\
\hline & $70 / 30$ & -0.11 & 1.18 & -0.46 & \\
\hline & $60 / 40$ & -0.02 & 1.37 & -0.44 & \\
\hline
\end{tabular}

*Enthalpy-entropy ratios Q, relative contribution of enthalpy and entropy to the enantioseparation at $303 \mathrm{~K}$.

TABLE 3: Temperature dependence of thermodynamic parameters with n-hexane (0.1\%TFA)-2-propanol 60/40 (v/v) as mobile phase.

\begin{tabular}{lccccccc}
\hline Compound & Temperature $\left({ }^{\circ} \mathrm{C}\right)$ & $\Delta H_{S}^{\circ}$ & $\Delta H_{R}^{\circ}$ & $\Delta S_{S}^{\circ}$ & $\Delta S_{R}^{\circ}$ & $\Delta G_{S}^{\circ}$ & $\Delta G_{R}^{\circ}$ \\
\hline \multirow{2}{*}{ Imazapyr } & 5 & 26.20 & 35.36 & 110.20 & 148.37 & -4.44 & -5.89 \\
& 10 & -48.55 & -49.26 & -156.29 & -153.32 & -5.10 & -6.64 \\
\hline \multirow{2}{*}{ Imazapic } & 5 & 30.30 & 22.62 & 124.43 & 101.60 & -4.29 & -5.62 \\
& 10 & -50.12 & -52.45 & -162.29 & -166.06 & -5.00 & -6.28 \\
\hline \multirow{2}{*}{ Imazethapyr } & 5 & 35.02 & 37.19 & 138.38 & 149.63 & -3.45 & -4.40 \\
& 10 & -49.25 & -51.14 & -162.05 & -165.32 & -4.20 & -5.18 \\
\hline \multirow{2}{*}{ Imazamox } & 5 & 22.99 & 25.09 & 100.97 & 112.16 & -5.08 & -6.09 \\
& 10 & -53.93 & -55.49 & -173.26 & -175.12 & -5.76 & -6.80 \\
\hline \multirow{2}{*}{ Imazaquin } & 5 & 29.29 & 31.80 & 123.25 & 133.58 & -4.97 & -5.34 \\
& 10 & -47.13 & -46.10 & -149.20 & -144.14 & -5.65 & -6.03 \\
\hline
\end{tabular}

3.1.2. Thermodynamic Parameters at $5-15^{\circ} \mathrm{C}$. The nonlinear van't Hoff plots in the range of $5-15^{\circ} \mathrm{C}$ caused temperaturedependent thermodynamic profile according to (6) (Table 3 ). The $\Delta H^{\circ}$ and $\Delta S^{\circ}$ values were negative at $10^{\circ} \mathrm{C}$ but positive at $5^{\circ} \mathrm{C}$ with $60 / 40$ mobile phase, indicating that the retention of enantiomers was entropy-driven at $5^{\circ} \mathrm{C}$ and enthalpydriven from 10 to $50^{\circ} \mathrm{C}$. For enantioselective separation, positive values of $\Delta\left(\Delta H^{\circ}\right)$ and $\Delta\left(\Delta S^{\circ}\right)$ at $5^{\circ} \mathrm{C}$ for imazapyr (1), imazethapyr (3), imazamox (4), and imazaquin (5) suggest entropy-driven (Table 4$)$. The $\Delta\left(\Delta H^{\circ}\right)$ and $\Delta\left(\Delta S^{\circ}\right)$ of imazapic (2) were negative at 5 to $10^{\circ} \mathrm{C}$. At $10^{\circ} \mathrm{C}$, imazapyr (1) and imazaquin (5) had positive $\Delta\left(\Delta S^{\circ}\right)$.

Nonlinear van't Hoff behaviors have been observed in many studies, for example, enantioseparation of dihydropyrimidinone on Chiralcel AD column [28], and a diol compound on Chiralcel OJ column [19]. Since small analytes were used, the $\mathrm{AD}$ and $\mathrm{OJ}$ phases based on polysaccharide were concluded to undergo thermally induced conformational 
TABLE 4: Temperature dependence of thermodynamic parameters for chiral separation with $n$-hexane (0.1\%TFA)-2-propanol 60/40 (v/v) as mobile phase.

\begin{tabular}{lccccc}
\hline Compound & $\begin{array}{c}\text { Temperature } \\
\left({ }^{\circ} \mathrm{C}\right)\end{array}$ & $\begin{array}{c}\Delta \Delta H^{\circ} \\
\mathrm{kJ} \mathrm{mol}^{-1}\end{array}$ & $\begin{array}{c}\Delta \Delta S^{\circ} \\
\mathrm{J} \mathrm{mol}^{-1} \mathrm{~K}^{-1}\end{array}$ & $\begin{array}{c}\Delta \Delta G^{\circ} \\
\mathrm{kJ} \mathrm{mol}^{-1}\end{array}$ & $Q$ \\
\hline \multirow{2}{*}{ Imazapyr } & 5 & 9.16 & 38.16 & -1.45 & 0.86 \\
& 10 & -0.71 & 2.97 & -1.54 & \\
\hline \multirow{2}{*}{ Imazapic } & 5 & -7.68 & -22.83 & -1.33 & 1.21 \\
& 10 & -2.33 & -3.77 & -1.28 & 2.19 \\
\hline \multirow{2}{*}{ Imazethapyr } & 5 & 2.18 & 11.25 & -0.95 & 0.70 \\
& 10 & -1.90 & -3.27 & -0.99 & 2.05 \\
\hline \multirow{2}{*}{ Imazamox } & 5 & 2.10 & 11.19 & -1.01 & 0.67 \\
& 10 & -1.56 & -1.86 & -1.04 & 2.97 \\
\hline \multirow{2}{*}{ Imazaquin } & 5 & 2.51 & 10.33 & -0.36 & 0.87 \\
& 10 & 1.03 & 5.07 & -0.38 & 0.72 \\
\hline
\end{tabular}

changes. On the other hand, nonlinear van't Hoff plots are usually observed for polymeric analytes such as polypeptide and protein due to their interactions with nonpolar nalkyl stationary phase in hydrophobic environments. These nonlinear van't Hoff plots were a result of the conformational changes of analytes [12]. However, nonlinear van't Hoff plots were also found for small analyte on a small molecule stationary phase derived from $(R)-\mathrm{N}$-(3,5-dinitrobenzoyl) phenylglycine. This unusual behavior was assigned to the temperature-dependent interaction of 2-propanol with the stationary phase and/or the analyte [29]. It showed thereby that the origin of the nonlinear van't Hoff behaviors may result from conformational changes of stationary phases, analyte, or their combinations. In the case of this study, more likely, the conformation change of the OJ phase caused the nonlinear van't Hoff plots under the low temperature [19].

3.2. Effect of Mobile Phase Composition on Thermodynamic Parameters. Changes of $\Delta H^{\circ}$ for both of enantiomers followed the same trend. Generally, the $\Delta H^{\circ}$ increased with increasing 2-propanol concentration from $15 \%$ to $40 \%(\mathrm{v} / \mathrm{v})$ (Table 1). The differences of $\Delta H^{\circ}$ between using $15 \%$ and $40 \%$ 2-propanol concentrations were, respectively, 3.8 and $3.7 \mathrm{~kJ} \mathrm{~mol}^{-1}$ for the first- and second-eluted enantiomers of imazamox (4), which were the smallest changes among the five compounds. The corresponding differences were 5.5 and $5.6 \mathrm{~kJ} \mathrm{~mol}^{-1}$ for imazaquin (5), the greatest $\Delta H^{\circ}$ variations among the five compounds.

The overall dependence of $\Delta S^{\circ}$ on the 2-propanol content was different from the $\Delta H^{\circ}$. The $\Delta S^{\circ}$ values increased with 2propanol concentration increasing from 15 to $20 \%$, decreased from 20 to $30 \%$, and then increased again from 30 to $40 \%$. The minimum $\Delta S^{\circ}$ values for both enantiomers were obtained with 30\% 2-propanol.

The effect of 2-propanol concentration on $\Delta\left(\Delta H^{\circ}\right)$ and $\Delta\left(\Delta S^{\circ}\right)$ varied for different compounds. For example, the most negative $\Delta\left(\Delta H^{\circ}\right)$ was observed at $30 \%$-propanol content for imazapic (2), imazethapyr (3), and imazamox (4).
TABLE 5: The correlation coefficients $\left(r^{2}\right)$, compensation temperature $(\beta)$ and $\Delta G_{\beta}^{\circ}$ in enthalpy-entropy compensation.

\begin{tabular}{lcccccc}
\hline Mobile phases & $\left(r^{2}\right)_{S}$ & $\beta\left({ }^{\circ} \mathrm{C}\right)$ & $\Delta G_{\beta}^{\circ}$ & $\left(r^{2}\right)_{R}$ & $\beta\left({ }^{\circ} \mathrm{C}\right)$ & $\Delta G_{\beta}^{\circ}$ \\
\hline $85 / 15$ & 0.668 & -16.0 & -11.44 & 0.812 & 45.0 & -9.19 \\
$80 / 20$ & 0.718 & 2.2 & -9.10 & 0.837 & 53.4 & -7.34 \\
$75 / 25$ & 0.757 & 16.8 & -7.29 & 0.860 & 57.4 & -6.02 \\
$70 / 30$ & 0.788 & 25.7 & -6.09 & 0.888 & 64.2 & -4.76 \\
$60 / 40$ & 0.877 & 29.7 & -4.40 & 0.927 & 61.9 & -3.50 \\
\hline
\end{tabular}

At $40 \%$ of 2-propanol, $\Delta\left(\Delta H^{\circ}\right)$ of imazaquin (5) became zero, suggesting that the enantioseparation was completely entropy-driven. The $\Delta\left(\Delta S^{\circ}\right)$ decreased with increasing 2propanol content from 15 to $30 \%$ for imazapic (2), imazethapyr (3), and imazamox (4) and then increased with 2propanol content raising from 30 to $40 \%$. The most negative values of $\Delta\left(\Delta S^{\circ}\right)$ for imazapyr (1), imazapic (2), imazethapyr (3), and imazamox (4) were observed at 30\% 2-propanol content. Only imazaquin (5) remained positive $\Delta\left(\Delta S^{\circ}\right)$ over the entire range of 2-propanol content tested. Regardless of the enthalpy or entropy trends, $\Delta G^{\circ}$ and $\Delta\left(\Delta G^{\circ}\right)$ always increased with the increasing of 2-propanol content.

O'Brien et al. [19] reported that $\Delta\left(\Delta H^{\circ}\right)$, and $\Delta\left(\Delta S^{\circ}\right)$ of a diol compound over a temperate range of 20 to $50^{\circ} \mathrm{C}$ increased with increasing 2-propanol content from 30\% to $45 \%$, which is consistent with our observations for imazapyr (1), imazapic (2), imazethapyr (3), and imazamox (4) over the temperature range of 15 to $50^{\circ} \mathrm{C}$ and the 2-propanol content range of 30 to $40 \%$. Moreover, the dependences of $\Delta H^{\circ}$, $\Delta S^{\circ}, \Delta\left(\Delta H^{\circ}\right)$ and $\Delta\left(\Delta S^{\circ}\right)$ on 2-propanol content from 15 to $40 \%$ showed that there was a deviation at 30\% 2-propanol content. It implied that the conformation of OJ phase not only changed with temperature but also likely with the mobile phase composition [30].

\subsection{Enthalpy-Entropy Compensation for Retention and Enan-} tioseparation. Existence of EEC was revealed by high $r^{2}$ $(\geq 0.7)$ in linear regression between $\Delta H^{\circ}$ and $\Delta S^{\circ}$ for the temperature range of $15-50^{\circ} \mathrm{C}$ (Table 5). The $r^{2}$ was consistently greater for the $R(+)$ enantiomer than the $S(-)$ counterpart, indicating that the EEC was more significant for the $R(+)$ enantiomer. The EEC increased with increasing 2-propanol content in the mobile phase. The best correlation $\left(r^{2}=\right.$ $0.927)$ was observed for the $R(+)$ enantiomer with $60 / 40(\mathrm{v} / \mathrm{v})$ mobile phase. The EEC temperature was within the range of -16 to $30^{\circ} \mathrm{C}$ for the $S(-)$ enantiomer and 45 to $62^{\circ} \mathrm{C}$ for the $R(+)$ enantiomer.

A plot of $\Delta\left(\Delta H^{\circ}\right)$ versus $\Delta\left(\Delta S^{\circ}\right)$ over the temperature range of $15-50^{\circ} \mathrm{C}$ yielded $r^{2}$ of 0.994 and $\Delta\left(\Delta G^{\circ}\right)_{\beta}$ of 0.691 (Figure 3), indicating that EEC occurred in the chiral separation. The compensation temperature was $104^{\circ} \mathrm{C}$ although it is beyond the regular HPLC operational temperature. At this temperature, the separation factor for the five compounds calculated from (11) would be 1.24. The plot of $\Delta\left(\Delta H^{\circ}\right)$ versus $\Delta\left(\Delta S^{\circ}\right)$ over $5-10^{\circ} \mathrm{C}$ was also linear illustrating EEC existence in the chiral separation (Figure 3 ). However, different slopes 
TABLE 6: $\Delta\left(\Delta H_{e}^{\circ}\right)_{i-j}$ versus $\Delta\left(\Delta S_{e}^{\circ}\right)_{i-j}$ associated with various functionary substitutions using $85 / 15,80 / 20,75 / 25,70 / 30$, and $60 / 40$ mobile phases.

\begin{tabular}{|c|c|c|c|c|c|}
\hline \multirow{2}{*}{ Pairs of compound } & \multirow{2}{*}{$\begin{array}{c}\text { Changes of functional group } \\
\text { IN/OUT }\end{array}$} & \multicolumn{2}{|c|}{$S(-)$} & \multicolumn{2}{|c|}{$R(+)$} \\
\hline & & Slop & $r^{2}$ & Slop & $r^{2}$ \\
\hline Imazapyr-imazapic & $\mathrm{CH}_{3} / \mathrm{H}$ & 134 & 0.727 & 156 & 0.173 \\
\hline Imazapyr-imazethapyr & $\mathrm{CH}_{3} \mathrm{CH}_{2} / \mathrm{H}$ & 94 & 0.401 & 309 & 0.515 \\
\hline Imazapyr-imazamox & $\mathrm{CH}_{3} \mathrm{OCH}_{2} / \mathrm{H}$ & 343 & 0.998 & 341 & 0.999 \\
\hline Imazapyr-imazaquin & $\mathrm{C}_{4} \mathrm{H}_{4} / \mathrm{H}$ & 318 & 1 & 243 & 0.987 \\
\hline Imazapic-imazethapyr & $\mathrm{CH}_{3} \mathrm{CH}_{2} / \mathrm{CH}_{3}$ & -0.9 & 0 & 359 & 0.857 \\
\hline Imazapic-imazamox & $\mathrm{CH}_{3} \mathrm{OCH}_{2} / \mathrm{CH}_{3}$ & 241 & 0.998 & 265 & 0.999 \\
\hline Imazapic-imazaquin & $\mathrm{C}_{4} \mathrm{H}_{4} / \mathrm{CH}_{3}$ & 371 & 0.974 & 363 & 0.993 \\
\hline Imazethapyr-imazamox & $\mathrm{CH}_{3} \mathrm{OCH}_{2} / \mathrm{CH}_{3} \mathrm{CH}_{2}$ & 202 & 0.978 & 221 & 0.995 \\
\hline Imazethapyr-imazaquin & $\mathrm{C}_{4} \mathrm{H}_{4} / \mathrm{CH}_{3} \mathrm{CH}_{2}$ & 397 & 0.932 & 393 & 0.975 \\
\hline Imazamox-imazaquin & $\mathrm{C}_{4} \mathrm{H}_{4} / \mathrm{CH}_{3} \mathrm{OCH}_{2}$ & 326 & 1 & 304 & 0.999 \\
\hline
\end{tabular}

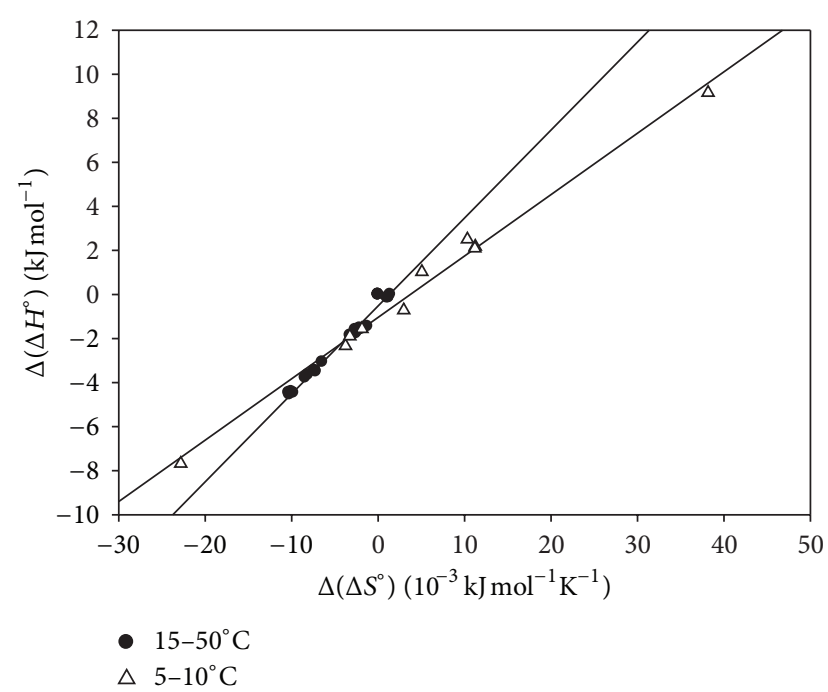

FigURE 3: Enthalpy-entropy compensation plot of $\Delta\left(\Delta H^{\circ}\right)$ versus $\Delta\left(\Delta S^{\circ}\right)$ at $5-10^{\circ} \mathrm{C}$ and $15-50^{\circ} \mathrm{C}$.

of the EEC curves confirmed different enantioseparation mechanisms. The EEC phenomenon in the enantioseparation conjoining the analogous chiral structure and the same elution order suggested that the five imidazolinone compounds possibly followed similar enantioseparation mechanism on the OJ column.

3.4. Enthalpy-Entropy Compensation in Additivity of Group Contribution. EEC associating with functional substitution in the imidazolinone homologous within $15-50^{\circ} \mathrm{C}$ was described as

$$
\Delta\left(\Delta S_{e}^{\circ}\right)_{i-j}=m_{e} \Delta\left(\Delta H_{e}^{\circ}\right)_{i-j}+n_{e}
$$

where $m_{e}$ and $n_{e}$ represented the slope and intercept. Results of $\Delta\left(\Delta H_{e}^{\circ}\right)_{i-j}$ versus $\Delta\left(\Delta S_{e}^{\circ}\right)_{i-j}$ associated with single functionary substitution across the $85 / 15,80 / 20,75 / 25$, $70 / 30$, and 60/40 mobile phases are listed in Table 6. In

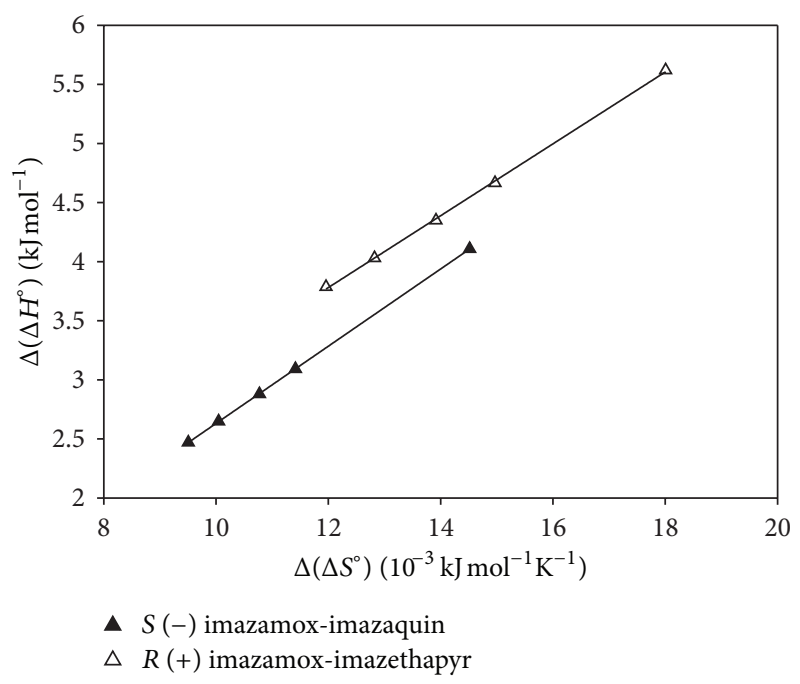

FIGURE 4: Enthalpy-entropy compensation of group selectivity for mobile phase composition.

the column of changes of functional group, IN indicates an introduced group, while OUT indicates a replaced group. The large $r^{2}$ indicated that EEC of group substitution for $S(-)$ or $R(+)$ enantiomer occurred. For example, good linear correlation relationships of $\Delta\left(\Delta H_{e}^{\circ}\right)$ versus $\Delta\left(\Delta S_{e}^{\circ}\right)$ for imazamox (4)-imazaquin (5), and imazamox (4)imazethapyr (3) are plotted in Figure 4. Very weak EEC appeared for $S(-)$ enantiomers among imazapyr (1), imazapic (2), and imazethapyr (3), while $S(-)$ and $R(+)$ imazamox (4) impressively showed the EEC interaction with all the other enantiomers.

Results of $\Delta\left(\Delta H_{e}^{\circ}\right)_{i-j}$ versus $\Delta\left(\Delta S_{e}^{\circ}\right)_{i-j}$ in single mobile phase, for example, $85 / 15$, across all ten functional substitutions of the homologous series are listed in Table 7 . The $r^{2}$ for both $S(-)$ and $R(+)$ enantiomers increasing with the increase of 2-propanol concentration revealed that more obvious EEC interactions were induced by the organic modifier. Moreover, the slopes were found having good linear correlation 
TABLE 7: Linear correlation relationship of $\Delta\left(\Delta H_{e}^{\circ}\right)_{i-j}$ versus $\Delta\left(\Delta S_{e}^{\circ}\right)_{i-j}$ in a single mobile phase across all ten functionary substitutions within the homolog.

\begin{tabular}{|c|c|c|c|c|c|c|}
\hline \multirow{2}{*}{ 2-propanol concentration } & \multicolumn{3}{|c|}{$S(-)$} & \multicolumn{3}{|c|}{$R(+)$} \\
\hline & Slope $m_{e}$ & Intercept $n_{e}$ & $r^{2}$ & Slope $m_{e}$ & Intercept $n_{e}$ & $r^{2}$ \\
\hline $15 \%$ & 0.211 & -0.45 & 0.694 & 0.261 & 0.274 & 0.71 \\
\hline $20 \%$ & 0.228 & -0.441 & 0.737 & 0.276 & 0.19 & 0.758 \\
\hline $25 \%$ & 0.243 & -0.417 & 0.775 & 0.285 & 0.133 & 0.805 \\
\hline $30 \%$ & 0.254 & -0.393 & 0.806 & 0.296 & 0.087 & 0.845 \\
\hline $35 \%$ & 0.267 & -0.316 & 0.894 & 0.295 & 0.086 & 0.905 \\
\hline
\end{tabular}

TABLE 8: $\Delta\left(\Delta G_{e}^{\circ}\right)_{i-j, 303 \mathrm{~K}}$ versus 2-propanol concentration in the mobile phase associated with various functionary substitutions.

\begin{tabular}{|c|c|c|c|c|c|}
\hline \multirow{2}{*}{ Pairs of compound } & \multirow{2}{*}{$\begin{array}{c}\text { Changes of functional group } \\
\text { IN/OUT }\end{array}$} & \multicolumn{2}{|c|}{$S(-)$} & \multicolumn{2}{|c|}{$R(+)$} \\
\hline & & Slop $a_{\varphi}$ & $r^{2}$ & Slop $a_{\varphi}$ & $r^{2}$ \\
\hline Imazapyr-imazapic & $\mathrm{CH}_{3} / \mathrm{H}$ & 1.16 & 0.992 & 1.48 & 0.987 \\
\hline Imazapyr-imazethapyr & $\mathrm{CH}_{3} \mathrm{CH}_{2} / \mathrm{H}$ & 1.92 & 0.988 & 2.24 & 0.981 \\
\hline Imazapyr-imazamox & $\mathrm{CH}_{3} \mathrm{OCH}_{2} / \mathrm{H}$ & 0.32 & 0.955 & 0.72 & 0.973 \\
\hline Imazapyr-imazaquin & $\mathrm{C}_{4} \mathrm{H}_{4} / \mathrm{H}$ & -0.22 & 0.644 & 0.74 & 0.986 \\
\hline Imazapic-imazethapyr & $\mathrm{CH}_{3} \mathrm{CH}_{2} / \mathrm{CH}_{3}$ & 0.72 & 0.973 & 0.76 & 0.958 \\
\hline Imazapic-imazamox & $\mathrm{CH}_{3} \mathrm{OCH}_{2} / \mathrm{CH}_{3}$ & 0.86 & 0.988 & -0.74 & 0.992 \\
\hline Imazapic-imazaquin & $\mathrm{C}_{4} \mathrm{H}_{4} / \mathrm{CH}_{3}$ & -1.4 & 0.959 & -0.76 & 0.958 \\
\hline Imazethapyr-imazamox & $\mathrm{CH}_{3} \mathrm{OCH}_{2} / \mathrm{CH}_{3} \mathrm{CH}_{2}$ & -1.6 & 0.993 & -1.58 & 0.991 \\
\hline Imazethapyr-imazaquin & $\mathrm{C}_{4} \mathrm{H}_{4} / \mathrm{CH}_{3} \mathrm{CH}_{2}$ & -2.12 & 0.965 & -1.52 & 0.958 \\
\hline Imazamox-imazaquin & $\mathrm{C}_{4} \mathrm{H}_{4} / \mathrm{CH}_{3} \mathrm{OCH}_{2}$ & -0.54 & 0.786 & 0.02 & 0.011 \\
\hline
\end{tabular}

relationships against the 2-propanol concentration, $\varphi$, for $S(-)\left(r^{2}=0.993\right)$ and $R(+)\left(r^{2}=0.912\right)$ enantiomers:

$$
m_{e}=c_{e} \varphi+d_{e}
$$

where $c_{e}$ and $c_{e}$ denote the slop and intercept. The $c_{e}$ for $S(-)$ enantiomers $\left(c_{e}=0.276\right)$ was larger than for $R(+)$ enantiomers $\left(c_{e}=0.176\right)$. Consequently, an iso- $m_{e}$ point of $S(-)$ and $R(+)$ enantiomers could be calculated by

$$
\varphi=\frac{d_{2}-d_{1}}{c_{1}-c_{2}}
$$

to give $\varphi=60.6 \%$. Below this concentration, EEC of the functional substitution was greater for $R(+)$ enantiomer than $S(-)$ and vice versa.

The standard Gibbs energy variation $\left(\Delta\left(\Delta G_{\mathrm{e}}^{\circ}\right)_{i-j}\right)$ causing from the functional substitution within $15-50^{\circ} \mathrm{C}$ also showed dependence on $\varphi$ :

$$
\Delta\left(\Delta G_{e}^{\circ}\right)_{i-j}=a_{\varphi} \varphi+b_{\varphi}
$$

where $a_{\varphi}$ and $b_{\varphi}$ represented the slop and intercept. Results of linear regression according to (14) for $\Delta\left(\Delta G_{e}^{\circ}\right)_{i-j}$ at $303 \mathrm{~K}$ are listed in Table 8 . The large $r^{2}$ indicated that the majority of the $\Delta\left(\Delta G_{e}^{\circ}\right)_{i-j}$ values, except for imazamox (4)-imazaquin (5), exhibited linear dependence on the 2-propanol concentration.

\section{Conclusion}

The retention of enantiomer was entropy-driven at $5^{\circ} \mathrm{C}$ and enthalpy-driven at 10 to $50^{\circ} \mathrm{C}$. The enantioseparation of imazapyr (1), imazapic (2), imazethapyr (3), and imazamox (4) was enthalpy-driven, whereas chiral separation of imazaquin (5) was entropy-driven. Enantioseparation mechanisms were different between $5-10^{\circ} \mathrm{C}$ and $15-50^{\circ} \mathrm{C}$, which was probably induced by the conformational change of the $\mathrm{OJ}$ phase. The EEC showed that the mechanisms of retention and enantioseparation for the five $S(-)$ or $R(+)$ enantiomers were very similar. The EEC in additivity of group contribution concurred with this observation. This study serves as a demonstration to yield useful information by utilizing distribution constant $K$ for understanding enantioseparation mechanism.

\section{Acknowledgment}

The author is indebted to Professor Jay Gan for supporting this work.

\section{References}

[1] A. Cavazzini, L. Pasti, A. Massi, N. Marchetti, and F. Dondi, "Recent applications in chiral high performance liquid chromatography: a review," Analytica Chimica Acta, vol. 706, no. 2, pp. 205-222, 2011. 
[2] K. B. Lipkowitz, "Atomistic modeling of enantioselection in chromatography," Journal of Chromatography A, vol. 906, no. 12, pp. 417-442, 2001.

[3] M. Lämmerhofer, "Chiral recognition by enantioselective liquid chromatography: Mechanisms and modern chiral stationary phases," Journal of Chromatography A, vol. 1217, no. 6, pp. 814856, 2010.

[4] L. Asnin, "Adsorption models in chiral chromatography," Journal of Chromatography A, vol. 1269, pp. 3-25, 2012.

[5] H. Kim, K. Kaczmarski, and G. Guiochon, “Thermodynamic analysis of the heterogenous binding sites of molecularly imprinted polymers," Journal of Chromatography A, vol. 1101, no. 1-2, pp. 136-152, 2006.

[6] T. Rojkovičová, J. Lehotay, D. Meričko, J. Čižmárik, and D. W. Armstrong, "Study of the mechanism of enantioseparation. IX. Effect of temperature on retention of chiral compounds on a methylated teicoplanin chiral stationary phase," Journal of Liquid Chromatography and Related Technologies, vol. 27, no. 16, pp. 2477-2494, 2004.

[7] K. G. Gebreyohannes and V. L. McGuffin, "Thermodynamic and kinetic study of chiral separations of coumarin-based anticoagulants on derivatized amylose stationary phase," Journal of Chromatography A, vol. 1217, no. 38, pp. 5901-5912, 2010.

[8] H. Kim, F. Gritti, and G. Guiochon, "Effect of the temperature on the isotherm parameters of phenol in reversed-phase liquid chromatography," Journal of Chromatography A, vol. 1049, no. 1-2, pp. 25-36, 2004.

[9] K. Miyabe, Y. Matsumoto, and G. Guiochon, "Peak parkingmoment analysis. A strategy for the study of the mass-transfer kinetics in the stationary phase," Analytical Chemistry, vol. 79, no. 5, pp. 1970-1982, 2007.

[10] K. Miyabe and G. Guiochon, "Thermodynamic interpretation of retention equilibrium in reversed-phase liquid chromatography based on enthalpy-entropy compensation," Analytical Chemistry, vol. 74, no. 23, pp. 5982-5992, 2002.

[11] K. Miyabet and G. Guiochon, "Extrathermodynamic relationships in reversed-phase liquid chromatography," Analytical Chemistry, vol. 74, no. 22, pp. 5754-5765, 2002.

[12] M. T. W. Hearn and G. Zhao, "Investigations into the thermodynamics of polypeptide interaction with nonpolar ligands," Analytical Chemistry, vol. 71, no. 21, pp. 4874-4885, 1999.

[13] A. Vailaya and C. Horváth, "Exothermodynamic relationships in liquid chromatography," Journal of Physical Chemistry B, vol. 102, no. 4, pp. 701-718, 1998.

[14] T. L. Chester and J. W. Coym, "Effect of phase ratio on van't Hoff analysis in reversed-phase liquid chromatography, and phaseratio-independent estimation of transfer enthalpy," Journal of Chromatography A, vol. 1003, no. 1-2, pp. 101-111, 2003.

[15] E. Grushka, H. Colin, and G. Guiochon, "Retention behavior of alkylbenzenes as a function of temperature and mobile phase composition in reversed-phase chromatography," Journal of Chromatography A, vol. 248, no. 3, pp. 325-339, 1982.

[16] L. A. Cole, J. G. Dorsey, and K. A. Dill, "Temperature dependence of retention in reversed-phase liquid chromatography. 2. Mobile-phase considerations," Analytical Chemistry, vol. 64, no. 13, pp. 1324-1327, 1992.

[17] L. Asnin, K. Sharma, and S. W. Park, "Chromatographic retention and thermodynamics of adsorption of dipeptides on a chiral crown ether stationary phase," Journal of Separation Science, vol. 34, no. 22, pp. 3136-3144, 2011.
[18] W. Lao and J. Gan, "High-performance liquid chromatographic separation of imidazolinone herbicide enantiomers and their methyl derivatives on polysaccharide-coated chiral stationary phases," Journal of Chromatography A, vol. 1117, no. 2, pp. 184193, 2006.

[19] T. O'Brien, L. Crocker, R. Thompson et al., "Mechanistic aspects of chiral discrimination on modified cellulose," Analytical Chemistry, vol. 69, no. 11, pp. 1999-2007, 1997.

[20] G. W. Kang, J. H. Ko, and W. J. Cheong, “Thermodynamic study of enantioseparation of arylpropionic acids with a Chiralcel OJ-H stationary phase," Journal of Liquid Chromatography and Related Technologies, vol. 28, no. 4, pp. 513-526, 2005.

[21] B. Chankvetadze, "Recent developments on polysaccharidebased chiral stationary phases for liquid-phase separation of enantiomers," Journal of Chromatography A, vol. 1269, pp. 26$51,2012$.

[22] M. Los, The Imidazolinone Herbicides., CRC press, Boca Raton, FL, USA, 1991.

[23] R. R. Krug, W. G. Hunter, and R. A. Grieger, "Enthalpy-entropy compensation. 1. Some fundamental statistical problems associated with the analysis of van't hoff and arrhenius data," Journal of Physical Chemistry, vol. 80, no. 21, pp. 2335-2341, 1976.

[24] E. Yashima, C. Yamamoto, and Y. Okamoto, "NMR studies of chiral discrimination relevant to the liquid chromatographic enantioseparation by a cellulose phenylcarbamate derivative," Journal of the American Chemical Society, vol. 118, no. 17, pp. 4036-4048, 1996.

[25] J. A. Chiarotto and I. W. Wainer, "Determination of metyrapone and the enantiomers of its chiral metabolite metyrapol in human plasma and urine using coupled achiral-chiral liquid chromatography," Journal of Chromatography B, vol. 665, no. 1 , pp. 147-154, 1995.

[26] W. R. Oberleitner, N. M. Maier, and W. Lindner, "Enantioseparation of various amino acid derivatives on a quinine based chiral anion-exchange selector at variable temperature conditions. Influence of structural parameters of the analytes on the apparent retention and enantioseparation characteristics," Journal of Chromatography A, vol. 960, no. 1-2, pp. 97-108, 2002.

[27] L. Limsavarn and J. G. Dorsey, "Influence of stationary phase solvation on shape selectivity and retention in reversed-phase liquid chromatography," Journal of Chromatography A, vol. 1102, no. 1-2, pp. 143-153, 2006.

[28] F. Wang, R. M. Wenslow, T. M. Dowling, K. T. Mueller, I. Santos, and J. M. Wyvratt, "Characterization of a thermally induced irreversible conformational transition of amylose tris(3,5-dimethylphenylcarbamate) chiral stationary phase in enantioseparation of dihydropyrimidinone acid by quasiequilibrated liquid chromatography and solid-state NMR," Analytical Chemistry, vol. 75, no. 21, pp. 5877-5885, 2003.

[29] W. H. Pirkle, "Unusual effect of temperature on the retention of enantiomers on a chiral column," Journal of Chromatography, vol. 558, no. 1, pp. 1-6, 1991.

[30] A. M. Rizzi, "Band broadening in high-performance liquid chromatographic separations of enantiomers with swollen microcrystalline cellulose triacetate packings. II. Influence of eluent composition, temperature and pressure," Journal of Chromatography A, vol. 478, pp. 87-99, 1989. 

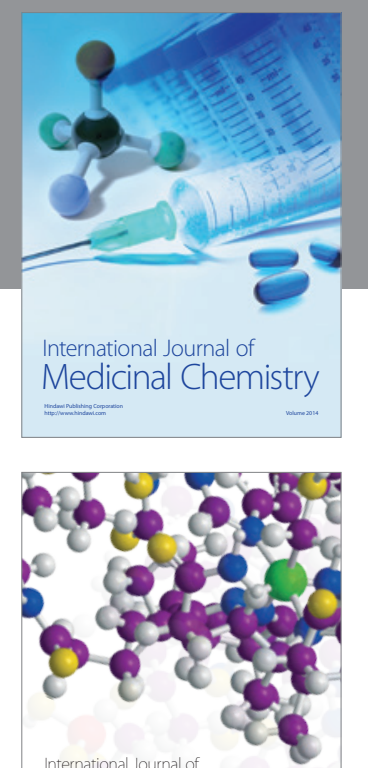

\section{Carbohydrate} Chemistry

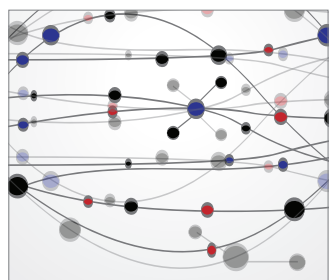

The Scientific World Journal
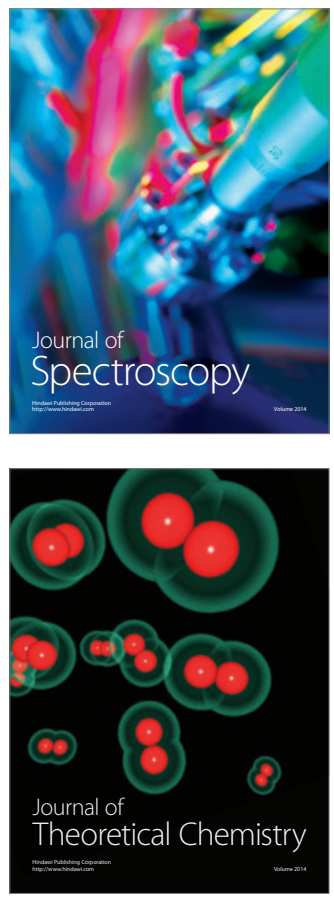
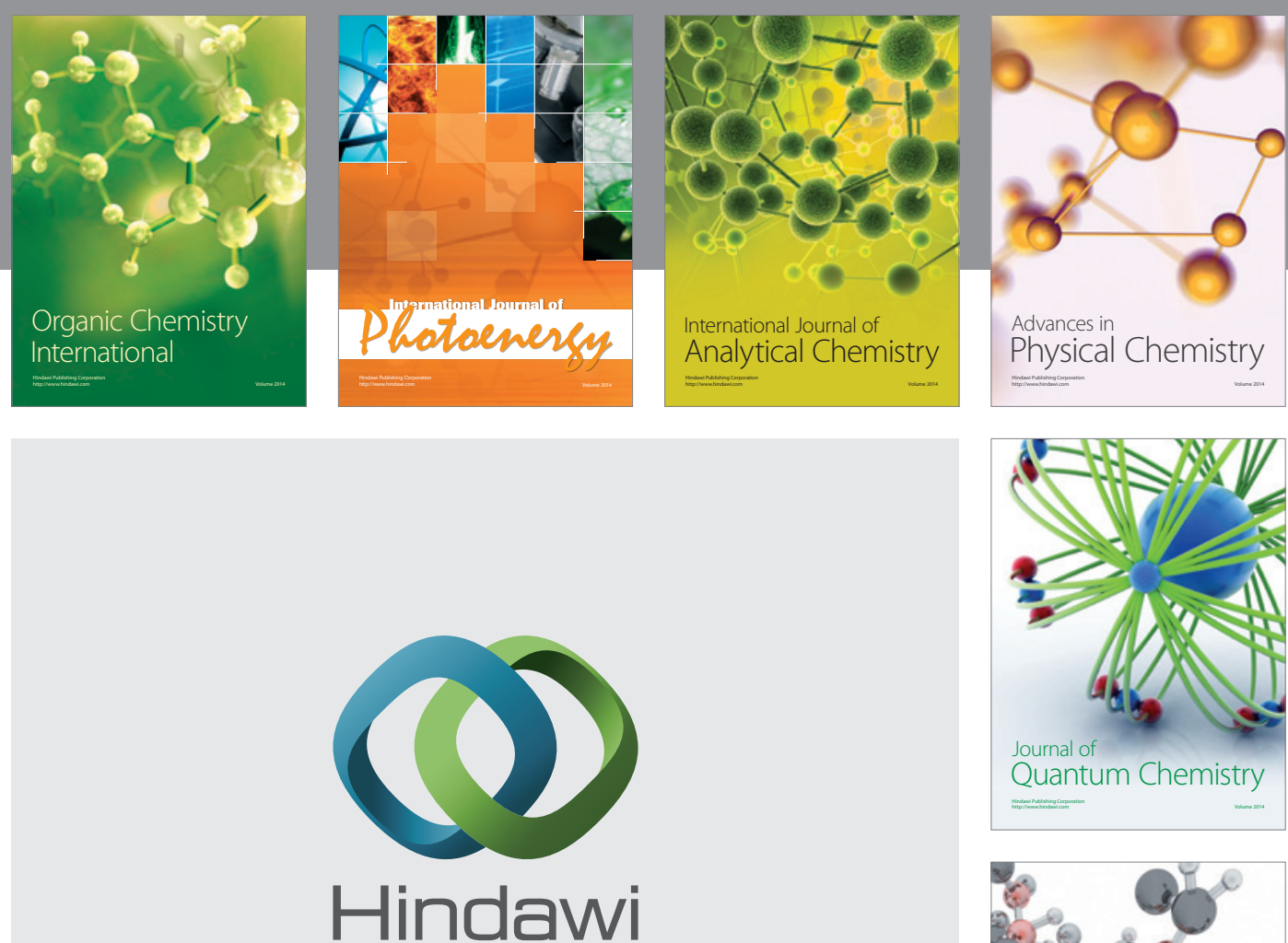

Submit your manuscripts at

http://www.hindawi.com

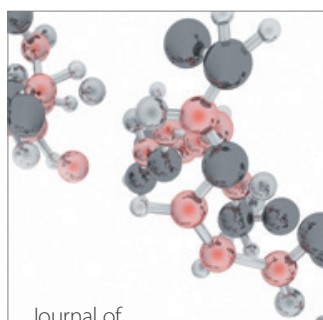

Analytical Methods

in Chemistry

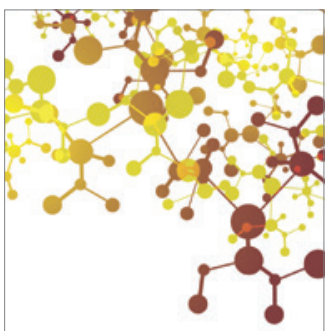

Journal of

Applied Chemistry

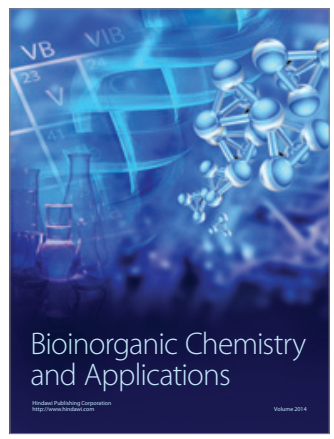

Inorganic Chemistry
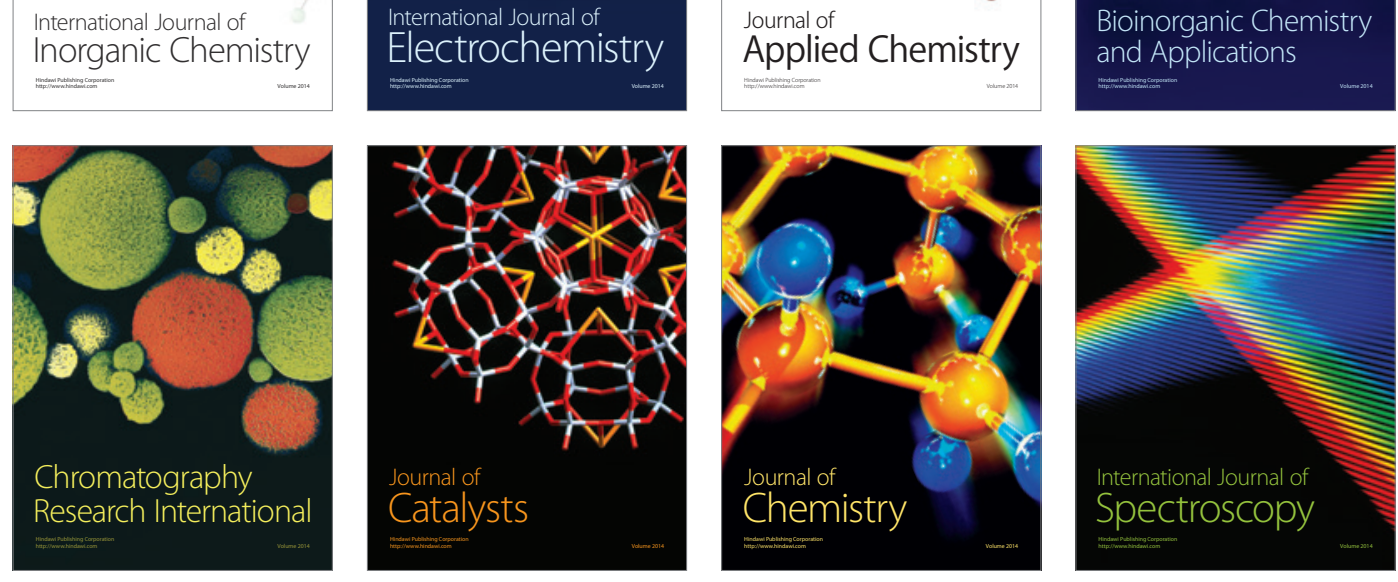